\title{
DEVELOPMENT OF SELECTED PARAMETERS OF MICROCLIMATE IN A STAND ALONE CELLAR PLUNGED INTO SOIL
}

\author{
Grzegorz Nawalany' ${ }^{1}$ Paweł Sokołowski' ${ }^{1}$ Piotr Herbut ${ }^{1}$, Sabina Angrecka ${ }^{1}$ \\ 1 Department of Rural Building, University of Agriculture in Krakow, al. Mickiewicza 24/28, 30-059 Kraków, \\ Poland, e-mail: g.nawalany@ur.krakow.pl
}

Received: 2017.03.04

Accepted: 2017.04.06

Published: 2017.05.02

\begin{abstract}
The thesis presents the analysis of development of selected parameters of microclimate in a standalone cellar plunged into soil. The scope of studies included measurement of air internal and external temperature and relative humidity of internal and external air. The thesis also concerns the analysis of heat exchange of cellar compartments with the surrounding soil. The studies were carried out from July 11, 2012 to July 10, 2013. The analysis of the obtained results of studies proved that the internal air temperature in the examined cellar was mainly formed by the external air temperature as well as by the surrounding soil. For $42 \%$ of storage period, the thermal conditions in the cellar plunged into soil were unfavorable which disqualifies the cellar's purpose for storage of vegetables, e.g. potatoes. Too high temperature was observed in the initial and final period. Favorable storage conditions were experienced only in the period from December 14, 2012 to April 11, 2013. To adjust this kind facility for storage of vegetables, thermal insulation of compartments and installation of cooling units is required.
\end{abstract}

Keywords: cellar plunged into soil, air temperature, air relative humidity, soil

\section{INTRODUCTION}

Even 20 years ago, cellars plunged into soil played an important role in storage of crops in Poland. Ground cellars in Pierzchnica are one of the largest complexes of this kind of facilities. It has been confirmed that there was a complex of a total of 82 cellars. These buildings were built for farmhouse purposes near residential houses and animal housing. Over the years, cellars in this area have become less popular, and now they are used in a small extent, while most of them require technical improvement (Kossakowski 2013). However, studies concerning cellar facilities in Grądy proved their significant use compared to the country. Several dozen cellars plunged into soil and partially plunged into soil have been found there (Więcek 2014). The number of buildings remaining in satisfactory conditions constituted $10 \%$ of all examined facilities.
Today, it is worth to consider the adaptation of the building plunged into soil that have a great potential of storage in agriculture. To qualify facilities of this kind for storage purposes, internal microclimate inside the building highly influenced by external air temperature must be recognized. It is especially important for storage of potato tuber whose quality gets extremely decreased due to too high temperature of storage (Zagórska and Grudzińska 2012, Murnice et al. 2011, Kaaber et al. 2002). Keeping temperature at the level from $4^{\circ} \mathrm{C}$ to $5^{\circ} \mathrm{C}$ limits germination and loss of turgidity, however it influences the accumulation of reducing sugars and sugar sums. Storage of tubers at the temperature of $8^{\circ} \mathrm{C}$ causes decrease in their quality due to loss of turgidity, resulting from excessive transpiration. The content of sugars is also reduced in higher temperatures (Zagórska and Grudzińska 2012, Mozolewski and Wieczorek 2002, Zgórska and Sowa-Niedziałkowska 2005). 
Another purpose for the use of existing plunged cellars may include their adaptation to wine cellars. This type of cellars is commonly found in Italy, Spain, and in Poland, in many regions, vineyards are established (Tinti et al. 2015, Tinti et al. 2014, Mazarron and Canas 2009). Nowadays, "energy awareness" in the modern, dynamically developing world makes scientists and engineers constantly search for new solutions that will help to reduce energy consumption of the building used in different economy sectors (Ruiz and Romero 2011, Sartori and Hestnes 2007). A number of standards and provisions of law determining requirements regarding efficiency and energy consumption of the buildings are created with the consideration of innovative technical solutions. To reduce energy needs, it is justified to use facilities plunged into soil. Soil thermal accumulation and its high thermal inertia may cause stabilization of internal air temperature and temperature of compartments that directly touch soil (Nawalany et al. 2014, Bieda et al. 2013). Studies carried out in Spain proved this argument and showed that internal temperature in traditional wine cellars plunged into soil depends mainly on the temperature of soil touching external compartments of a building (Ocana and Guerrero 2006).

Due to the need of increasing energy effectiveness of storage buildings, modern technical solutions are used to ensure a control over selected parameters of internal microclimate. With regard to this point, wine cellars require special attention, as the temperature and humidity of internal air are of the greatest importance for the final quality of wine. For this reason, using facilities plunged into soil for wine purposes is justified. Benefits resulting from that do not only include the support of stabilization of internal microclimate but also this may lead to energy savings (Mazarron and $\mathrm{Ca}$ nas 2008). However, construction of the buildings plunged into soil requires increased finances and properly made waterproofing insulation. If the soil water table is highly located, water drainage should also be designed. In the buildings plunged into soil it is also difficult to ensure natural ventilation of interior (Martin and Canas 2006, AlTemeemi and Harris 2004).

The purpose of the work was to carry out the analysis of development of temperature and relative humidity of internal air in the cellar plunged into soil.

The scope of work included constant measurements of temperature and relative humidity of internal air in the cellar plunged into soil. Studies also concerned the measurements of air temperature around the floor and wall areas as well as temperature and relative humidity of external air. Calculations of heat exchange with the soil by the cellar flooring was also used in the studies.

\section{MATERIALS AND METHODS}

The cellar plunged into soil with the area of $5.5 \mathrm{~m}^{2}$ was the subject of the studies. The building is located in Grądy, małopolskie voivodship. The building has been constructed in the 70's of the last century. The studied cellar is a longitudinal axis in North-South direction. External walls and floor have been made of concrete, and the ceiling from the reinforced concrete. The west-side wall of the cellar touches the farmhouse on the west side. Other elevations are not shielded. The cellar is plunged into soil in $110 \mathrm{~cm}$ and covered with 30 centimeters of soil.

Field studies were carried out from July 11, 2013 to July 10, 2013. Portable USB Voltcraft DL-121TH recorders were used to measure temperature and relative humidity of internal air, air temperature around the floor and wall areas, and temperature and relative humidity of external air. Measurements of the above mentioned parameters were made every 60 minutes. Locations of measurement points in the cellar are presented in Figure 1.

Moreover, the calculation analysis of heat flow through the cellar's floor were also carried out. For this purpose, WUFIplus computer software was used. Calculations were made with a 1-hour time step assuming the measured temperature of internal and external air as boundary conditions.

\section{RESULTS}

The course of temperature and relative humidity of internal and external air is presented in Figure 2. Storage season has been divided into 3 periods: initial (from October 1, 2012 to November 28, 2012), middle (from November 29, 2012 to April 11, 2013) and final (from April 12, 2013 to June 1, 2013). The results of the studies of air temperature inside the cellar proved that during the whole study period the temperature value ranged from $1.2^{\circ} \mathrm{C}$ to $22.1^{\circ} \mathrm{C}$. External temperature in this period developed from $-18.1^{\circ} \mathrm{C}$ 
a)

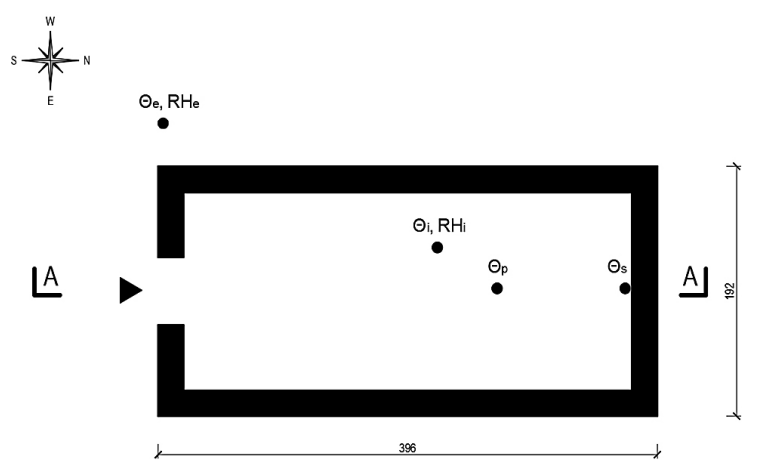

b)

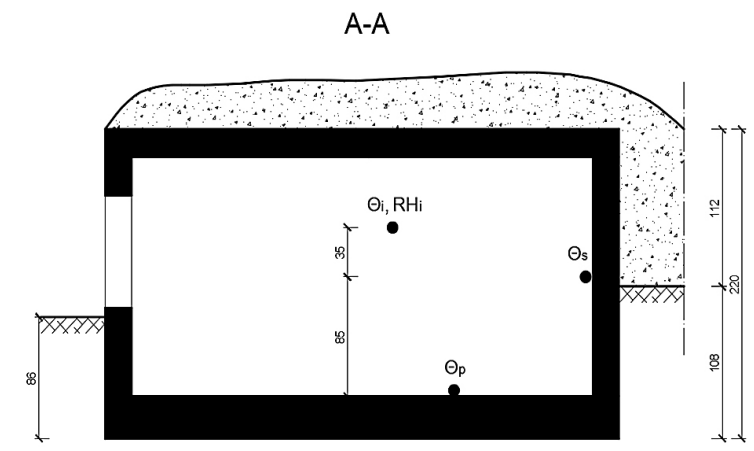

Figure 1. Location of measurement points of the temperature and relative humidity of air in the studied cellar plunged intro soil; a) view, b) section
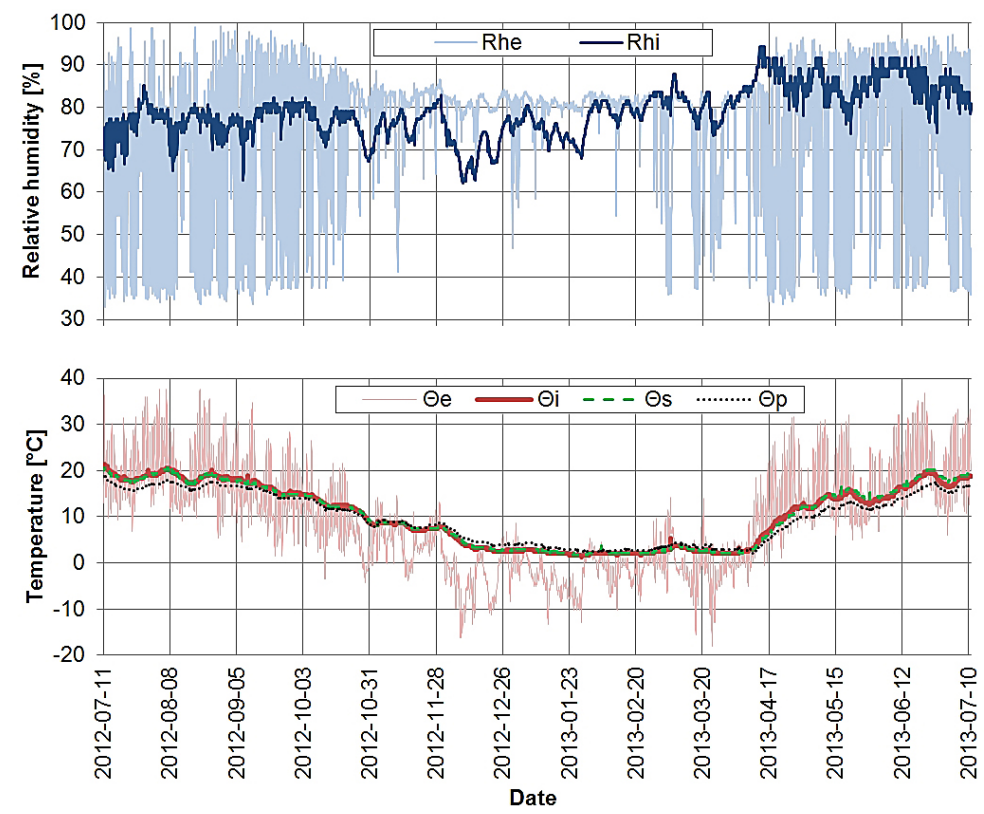

Figure 2. Course of external air relative humidity (Rhe) and internal air relative humidity (Rhi) and external air temperature $(\Theta e)$, internal air temperature $(\Theta i)$, air temperature in wall area $(\Theta s)$ air temperature in floor area

$(\Theta p)$ during the complete study period

to $38.1^{\circ} \mathrm{C}$. Internal air relative humidity ranged from $61.4 \%$ to $94.4 \%$, while the external air relative humidity did not drop below $33 \%$ and did not exceed $99.2 \%$. The average annual temperature value was $10.2^{\circ} \mathrm{C}$ (median of $11.4^{\circ} \mathrm{C}$ ) at a standard deviation of $6.6^{\circ} \mathrm{C}$. The average annual relative humidity of internal air was 79.1\% (median of $78.9 \%$ ), while a deviation from this parameter was $5.8 \%$. Air temperature at the floor area showed smaller annual amplitude $\left(17^{\circ} \mathrm{C}\right)$ compared to the internal air temperature in the middle part $\left(20.9^{\circ} \mathrm{C}\right)$ and around walls $\left(21.3^{\circ} \mathrm{C}\right)$. At the beginning and end of the storage period, unfavorable thermal conditions were observed inside the cellar. Temperatures favorable for vegetable stor- age, especially potato tubers, were observed only within the middle period.

Summer, winter and transitional week-based periods were chosen for detailed analysis of development of air temperature and relative humidity (Fig. 3). In the examined period, the external air temperature daily amplitude exceeded $20^{\circ} \mathrm{C}$. Internal air temperature ranged from $17.9^{\circ} \mathrm{C}$ to $21.7^{\circ} \mathrm{C}$. Internal air relative humidity ranged from $33 \%$ to $97.2 \%$, while the average value of this parameter was $73.6 \%$. The analysis of external air relative humidity showed a twice larger daily amplitude, compared to the external conditions. The average value of external air relative humidity was $65.5 \%$. 
a)
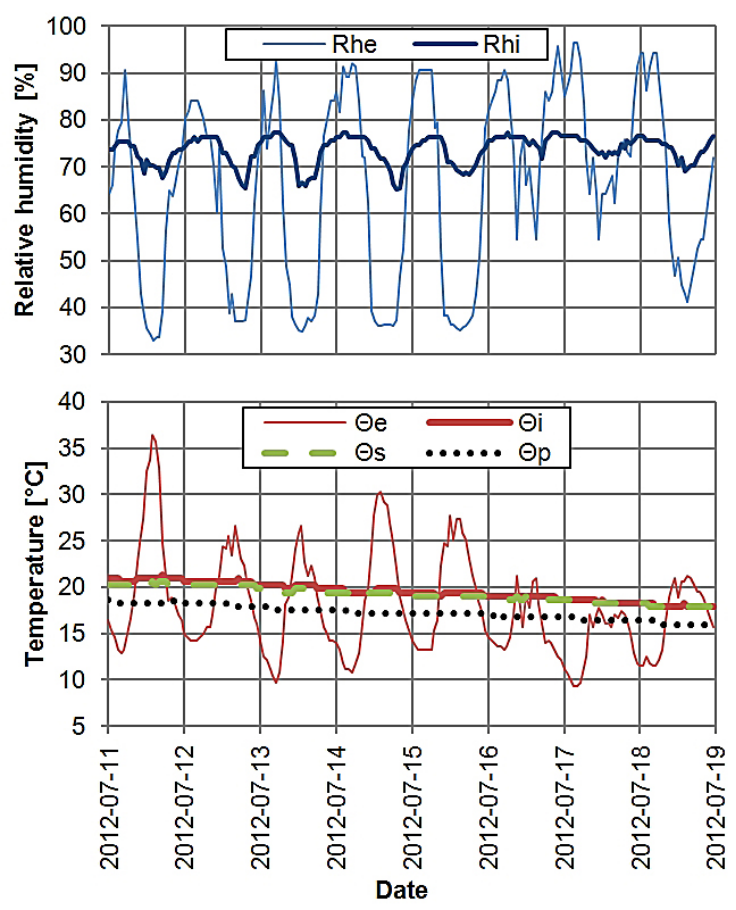

c)
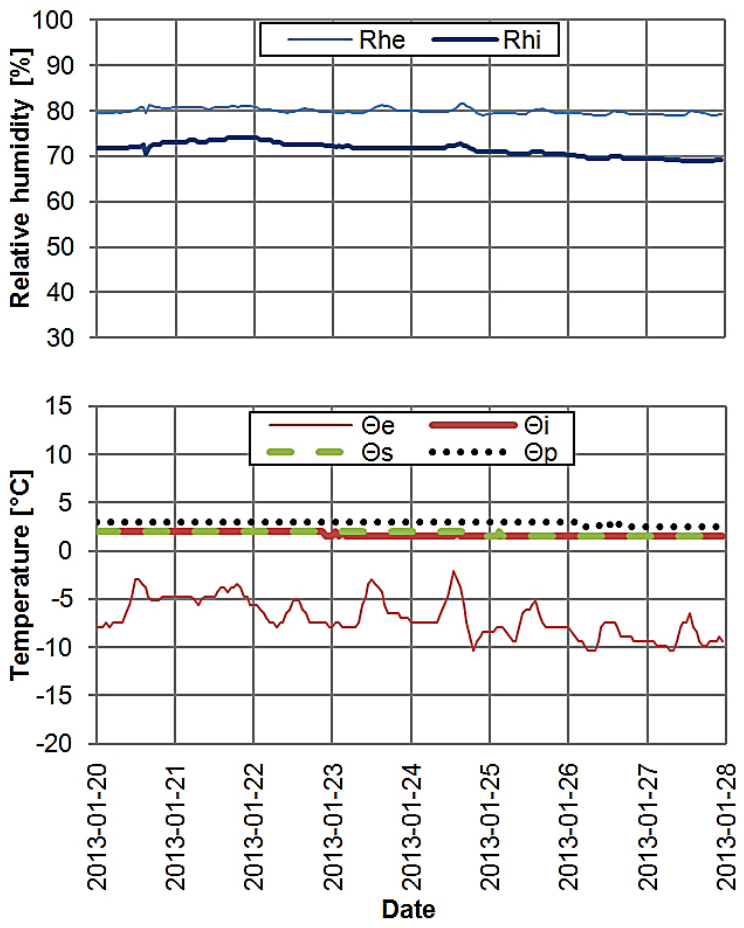

b)

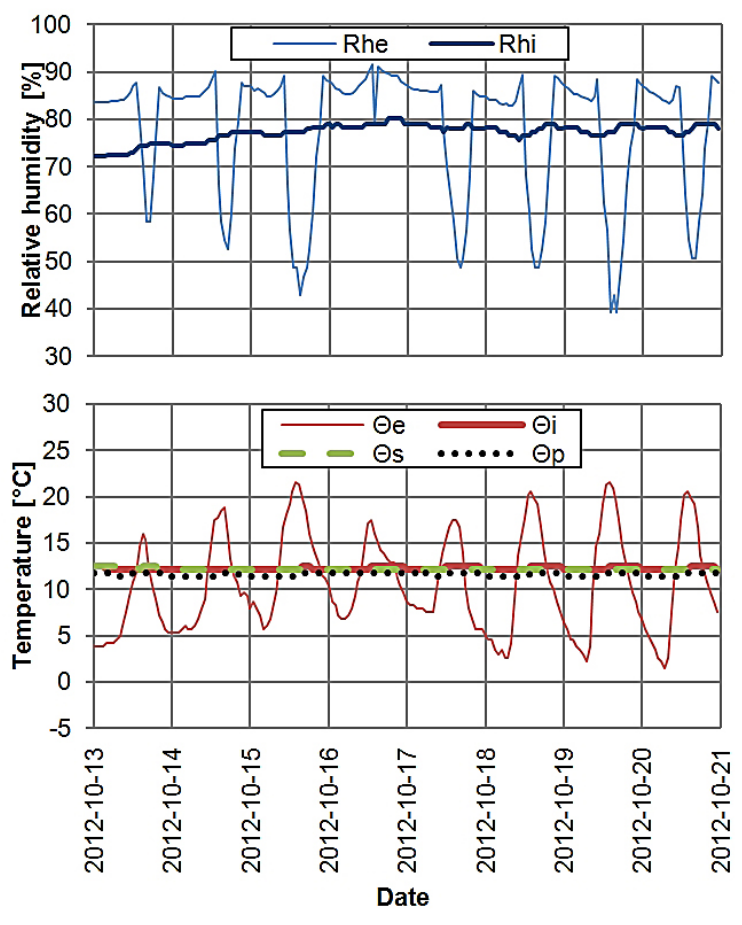

d)
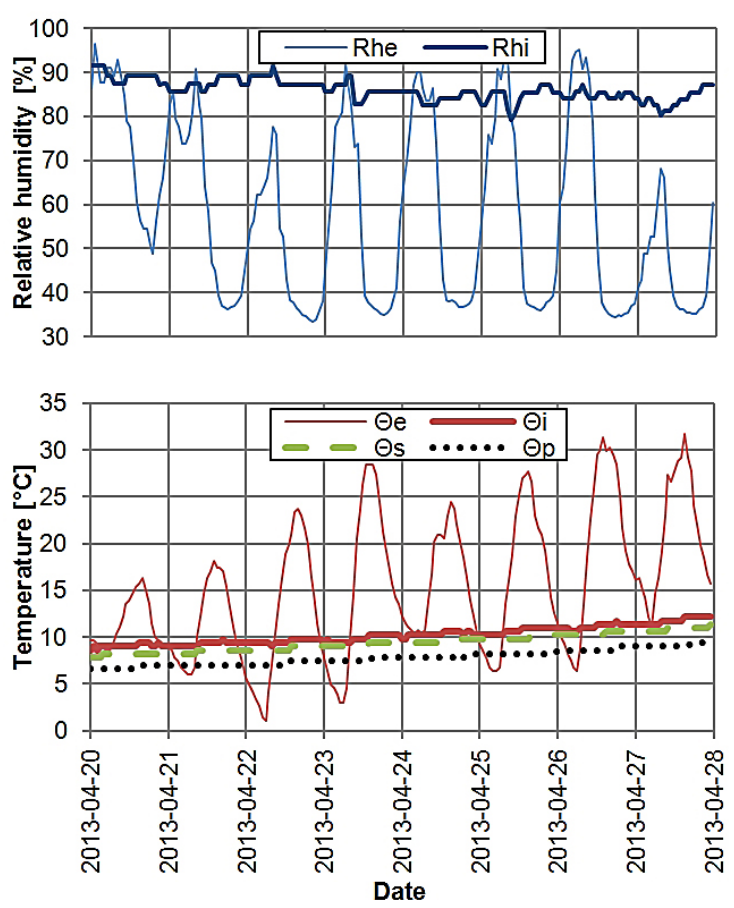

Figure 3. Course of external air relative humidity (Rhe) and internal air relative humidity (Rhi) and external air temperature $(\Theta \mathrm{e})$, internal air temperature $(\Theta \mathrm{i})$, air temperature in wall area $(\Theta \mathrm{s})$ air temperature in floor area $(\Theta \mathrm{p})$ during the following periods: a) 11.07.2012-19.07.2012, b) 13.10.2012-21.10.2012, c) 20.01.2013-28.01.2013, d) 20.04.2013-28.04.2013

In the autumn period, the external air relative humidity daily amplitude dropped and its value did not exceed 5\%. The external air relative humidity daily amplitude ranged from $25 \%$ to $49 \%$. The average values of internal and external air relative humidity equaled $77.2 \%$ and $78 \%$ respectively. The analysis of the studies' results on internal air temperature proved high stabil- 
ity of temperature in autumn. The minimum observed value of this parameter was $12.2^{\circ} \mathrm{C}$, and the maximum $-12.6^{\circ} \mathrm{C}$.

The analysis of the studies' results from winter period showed a significant drop of internal air temperature, whose average value was $1.8^{\circ} \mathrm{C}$. The temperature inside the cellar below $1.6^{\circ} \mathrm{C}$ was not observed, however, the highest value of this parameter in this period was $2.9^{\circ} \mathrm{C}$. In this period, internal air relative humidity and external air relative humidity was stable and did not show a daily amplitude above $2 \%$. Standard deviation of internal air relative humidity internal air relative humidity was $1.5 \%$, while external air relative humidity was $0.6 \%$. During the summer, autumn and spring period, differences of deviation of this parameter were even 7-times higher. In the winter period, contrary to the other analyzed periods, air temperature around the floor was higher than in the middle part of the facility by circa. $1^{\circ} \mathrm{C}$.

The results to the studies from spring period presented an increase in the average value of internal air temperature up to $10.2^{\circ} \mathrm{C}$. It was, however, lower by $5.2^{\circ} \mathrm{C}$ from the average external air temperature. In autumn when the cellar's internal microclimate was similar to the one from spring period, the average value of internal air temperature was higher by $1.7^{\circ} \mathrm{C}$ compared to the average external air temperature $\left(10.6^{\circ} \mathrm{C}\right)$.

The analysis of the existing cellar regarding its possible usage proved that the period from December to April was beneficial for storage of tuber vegetables, especially potatoes. In the period of harvest (second half of September), the internal microclimate was unfavorable and varied from the recommended temperature for storage of potatoes. Due to the development of internal air temperature during the year ranging from $1.2^{\circ} \mathrm{C}$ to $22.1^{\circ} \mathrm{C}$, with small expenses for heating and cooling, it is possible to use the examined facil- ity for storage of wine in the first year of wine treatment. Cellar adaptation would also require to plan the system maintaining relative humidity ranging from $70 \%$ to $98 \%$.

Heat exchange with soil has a significant impact on development of the cellar's internal temperature. Figure 4 shows a daily heat flow through the cellar's floor.

The calculations of heat exchange between the cellar's internal air and the soil under the floor proved that from July 11, 2012 to December 4, 2012 the heat flowed from the soil to the interior of the cellar. The average daily value of heat loads in this period was $2.12 \mathrm{~kW}$. The largest heat loss to the soil by the floor took place from February 5, 2013 and was $3.80 \mathrm{~kW}$. The total amount of heat losses for the whole analyzed period was $167.84 \mathrm{kWh}$, while the heat loads amounted to $399.24 \mathrm{kWh}$.

\section{CONCLUSIONS}

For $42 \%$ of storage period, the thermal conditions in the cellar plunged into soil were unfavorable, what disqualifies the cellar's purpose for storage of vegetables, e.g. potatoes. Too high temperature was observed in the initial and final period. During the summer period, around the floor the temperature was lower from the temperatures of other areas inside the cellar. In the period of harvest (second half of September), the cellar's internal temperature was higher than the temperature required for storage of most of vegetables by $5^{\circ} \mathrm{C}-10^{\circ} \mathrm{C}$. Favorable conditions for storage were observed only from December 14, 2012 to April 11,2013 . Plunging the cellar into soil significantly impacts the stability of internal microclimate by means of decreasing daily fluctuations of temperature and internal air relative humidity. In the

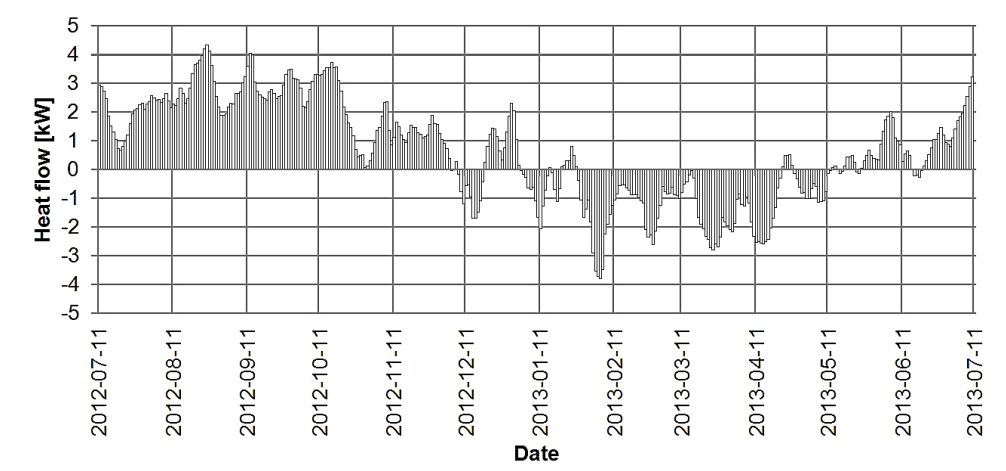

Figure 4. The calculated daily heat exchange between internal air and the soil under the floor 
winter period, the cellar's interior was heated by the heat flow from soil. This resulted in the floor area temperature higher by circa. $1^{\circ} \mathrm{C}$ compared to the middle part of the building.

The analysis of heat exchange between internal air and floor showed almost twice bigger impact of the soil under the floor on the heat loads (399.24 kWh) compared to the losses (167.84 $\mathrm{kWh}$ ). Soil heated the cellar in the initial period and cooled it in the final period. In the initial period of the storage season, the heat exchange with soil resulted in heat loads of $110.2 \mathrm{kWh}$, while in the final period, in losses of $25.2 \mathrm{kWh}$. Thermal condition analysis proved that the cellars of this kind that are plunged into soil may be adapted for storage of wine in the first period of wine treatment. However, to use them for storage of vegetables, thermal insulation of compartments and installation of cooling units is required.

\section{REFERENCES}

1. Al-Temeemi A.A., Harris D.J. 2004. A guideline for assessing the suitability of earthsheltered masshousing in hot-arid climates, Energy and Buildings 36, 251-260

2. Bieda W., Radoń J., Nawalany G. 2013. Wymiana ciepła między nieizolowaną termicznie oborą a gruntem $\mathrm{w}$ badaniach eksperymentalnych. Budownictwo i Architektura 12(3) (2013), 35-38

3. Kaaber L., Martinsen B.K., Bra E., Shomer J. 2002. Browning inhibition and textural changes of pre-peeled potatoes. Lebensmittelwiss. Technol., 35, 326-531

4. Kossakowski P. 2013. Zabytkowe piwnice ziemne w Pierzchnicy, Budownictwo i Architektura 12 (3), 263-270

5. Martin S., Canas I. 2006. A comparison between underground wine cellars and aboveground storage for the aging of Spanish wines, Transactions of the Asabe 49 (5), 1471-1478

6. Mazarron F.R., Canas I. 2008. Exponential sinusoidal model for predicting temperature inside underground wine cellars from a Spanish region, Energy and Buildings 40, 1931-1940

7. Mazarron F.R., Canas I. 2009. Seasonal analysis of the thermal behaviour of traditional underground wine cellars in Spain, Renewable Energy, Vol. 34, Issue 11, 2484-2492

8. Mozolewski W., Wieczorek J. 2002. Wpływ nawożenia azotem na ciemnienie enzymatyczne i nieenzymatyczne po zbiorze i w czasie przechowywania. Zesz. Prob. Post. Nauk Roln., 484, 393-400

9. Murnice I., Karklina D., Galoburda R., Santare D., Skrabule I., Costa H.S. 2011. Nutritional composition of freshly harvested and stored Latvian potato varieties depending on traditional cooking methods. J. of Food Composition and Analysis, 24, 699-710

10. Nawalany G., Bieda W., Radoń J., Herbut P. 2014. Experimental study on development of thermal conditions in ground beneath a greenhouse. Energy and Buildings, 69, 103-111.

11. Ocana S.M., Guerrero I.C. 2006. Comparison of analytical and on site temperature results on Spanish traditional wine cellars, Applied Thermal Engineering 26, 700-708

12. Ruiz M.C., Romero E. 2011. Energy saving in the conventional design of a Spanish house using thermal simulation, Energy and Buildings 43, 32263235

13. Sartori I., Hestnes A.G. 2007. Energy use in the life cycle of conventional and low-energy buildings: a review article, Energy and Buildings 39, 249-257

14. Tinti F., Barbaresi A., Benni S., Torreggiani D., Bruno R., Tassinari P. 2014. Experimental analysis of shallow underground temperature for theassessment of energy efficiency potential of underground wine cellars, Energy and Buildings 80, 451-460

15. Tinti F., Barbaresi A., Benni S., Torreggiani D., Bruno R., Tassinari P. 2015. Experimental analysis of thermal interaction between wine cellar and underground, Energy and Buildings 104, 275-286

16. Wiącek A. 2014. Analiza wybranych parametrów mikroklimatu piwnicy zagłębionej w gruncie. Niepublikowana praca magisterska, Katedra Budownictwa Wiejskiego, UR Kraków

17. Zagórska K., Grudzińska M. 2012. Zmiany wybranych cech jakości bulw ziemniaka w czasie przechowywania, Acta Agrophysica 19 (1), 203-214

18. Zgórska K., Sowa-Niedziałkowska G. 2005. Wpływ czynnika termicznego i odmianowego na zmiany jakościowe zachodzące w bulwach ziemniaka w czasie ich długotrwałego przechowywania. Pamiętnik Puławski, 139, 327-336 